\title{
Trend Shocks and Cyclicality of Gross Financial Flows
}

\author{
Eylem Ersal-Kiziler ${ }^{1}$ \\ ${ }^{1}$ College of Business and Economics, University of Wisconsin-Whitewater, Whitewater, USA \\ Correspondence: Eylem Ersal-Kiziler, University of Wisconsin-Whitewater, College of Business and Economics, \\ Department of Economics, Hyland Hall 809 W Starin Road, Whitewater, WI, 53190, USA. Tel: 1-262-472-5586. \\ E-mail: kizilere@uww.edu
}

Received: March 11, 2015

Accepted: March 19, 2015

Online Published: April 25, 2015

doi:10.5539/ijef.v7n5p1

URL: http://dx.doi.org/10.5539/ijef.v7n5p1

\begin{abstract}
This paper analyzes the behavior of international gross capital flows over the business cycle in a two-country DSGE portfolio choice model with shocks to both the transitory and trend components of the endowment. Empirical work on international capital flows documents weakly procyclical, and at times, countercyclical gross financial flows between economies. This observation cannot be reconciled with the predictions of the standard open economy model. These models typically employ transitory productivity shocks as the main driver of business cycles. However the recent theoretical and empirical literatures emphasize the importance of shocks to the trend component of output in matching business cycle moments with data. Our main finding is that transitory shocks result in strongly procyclical gross capital flows, while trend shocks yield weakly countercyclical gross outflows and weakly procyclical gross inflows. Overall, both the magnitude and the sign of correlation coefficients from our model are more consistent with the empirical evidence in the literature. We demonstrate that transitory shocks alone cannot produce results that are in line with the empirical evidence. This finding holds true for different levels of persistence of the transitory shocks. We illustrate that empirically sound predictions are the result of the separation of the transitory and trend shocks.
\end{abstract}

Keywords: capital flows, trend shocks, productivity, business cycles, portfolio choice, DSGE models

\section{Introduction}

Empirical work on cyclical properties of gross international capital flows is scarce in comparison to the amount of work on net capital flows (see, for example, Kaminsky, Reinhart, \& Végh, 2005; Forbes \& Warnock, 2012; Broner, Didier, Erce, \& Schmukler, 2013). Moreover, the findings of existing research are not aligned with predictions of the standard open economy model. Contessi, De Pace, and Francis (2013) perform one of the most extensive systematic analyses of the behavior of disaggregated capital flows at business cycle frequencies and delineate stylized facts on the cyclical properties of capital flows. They find that gross outflows and inflows in advanced economies are both procyclical. In emerging markets, gross outflows are countercyclical, while gross inflows are procyclical. Net capital outflows are countercyclical in both emerging market and advanced economies.

The standard open economy model predicts procyclical gross inflows and outflows. Net capital outflows are countercyclical only under very persistent transitory endowment shocks. In the case of less persistent transitory shocks, which revert to the trend quicker, the model produces procyclical net capital outflows. This prediction of the model is at odds with the data. Therefore, these models either employ very persistent transitory productivity shocks or use other shocks as the main drivers of business cycles. This paper analyzes the behavior of international gross capital flows over the business cycle in a two-country DSGE model with shocks to both the transitory and trend components of the endowment. Recent theoretical and empirical efforts emphasize the importance of shocks to the trend component of output in matching business cycle moments with data (See Aguiar \& Gopinath, 2007; Blonigen, Piger, \& Sly, 2013; Amdur \& Ersal-Kiziler, 2014). Aguiar and Gopinath (2007) (AG, hereafter) analyze the effects of trend and transitory productivity shocks on agents' optimizing behavior and implied business cycle moments. They document that trend shocks account for $61 \%$ and $84 \%$ of output growth fluctuations in advanced and developing economies, respectively. Amdur and Ersal-Kiziler (2014) (AEK, hereafter) estimate that trend shocks for the U.S. are 1.8 times as volatile as transitory shocks. They also document that at a horizon of 4 quarters, over $50 \%$ of variation in U.S. current-account-to-GDP ratio comes from trend shocks, assuming there is no cross-country correlation. In the case of positive cross-country correlations, 
$96 \%$ of the variation is attributed to home and foreign trend shocks.

Our study does not claim that trend and transitory productivity shocks are sufficient to account for all observed macroeconomic dynamics. Garcia-Cicco, Pancrazi, and Uribe (2010) estimate the small open economy RBC model in AG for Mexico and Argentina. They find that an augmented model with preference shocks, country-premium shocks and a realistic debt elasticity of country premium performs better than the AG model with productivity shocks only in matching business cycle moments. In a similar model to ours Couerdacier, Kollman, and Martin (2010) study international portfolios with the presence of demand and redistributive shocks as well as endowments shocks. Using a particular asset market structure and with capital accumulation, they are able to reproduce observed cyclical dynamics of foreign assets. They argue that each of these shocks serve as a particular channel creating necessary risk-sharing and hedging motives in arriving at the equilibrium portfolio. One can extend this list to add interest rate shocks, investment shocks, monetary and fiscal policy shocks as well as financial frictions, all potentially important elements to create realistic models with realistic business cycle moments. However, in a study of G7 economies over 1960-2005, Crucini, Kose and Otrok (2013) demonstrate that productivity remains to be the main driver of international business cycles. Therefore, while other aggregate shocks and financial frictions are also important, we argue that it is worthwhile to explore the impact of trend and transitory fluctuations in output on portfolio choices and hence financial flows in an otherwise basic model stripped off all the bells and whistles mentioned above.

Trend shocks, that are shocks to the growth rate of productivity, influence the direction of financial flows differently compared to persistent transitory shocks. Following an endowment shock, households adjust their consumption path to the extent that permanent income changes relative to the current level of income. Trend shocks create changes in the consumption path of the households. With transitory shocks, consumption-smoothing households do not alter their consumption path significantly in response to the change in the endowment and as such the model fails to yield the observed volatility in consumption, which is an important factor in determining the direction of financial flows. Moreover, the observed heterogeneity in cyclical dynamics of financial flows across countries is aligned with the variation in the relative volatility of trend and transitory shocks to productivity across countries.

Our work is related to the strand of economic literature that studies international financial assets and liabilities as country portfolios and investigates the impact of exogenous shocks on these portfolios (e.g., Devereux \& Sutherland, 2010, 2011; Evans \& Hnatkovska, 2012; Tille \& Van Wincoop, 2010). This paper is the first one that analyzes the gross financial flows with trend and transitory shocks in a two-country setting with an explicitly modeled portfolio choice problem. AG study trade balance in a single country setup under a similar productivity process. Chen and Crucini (2014) argue that, even within a small open economy model that contains a single country, and assumes exogenous interest rates, errors result in estimating the importance of trend and transitory components because it ignores cross-country productivity correlations and spillovers. They advocate for a two-country general equilibrium setup, even when a small economy is being analyzed. The stochastic properties of the productivity processes we employ are parameterized to mimic the U.S. and the rest of the G7 countries, which obliges the use of a two-country DSGE framework. AEK study a similar model to ours with capital accumulation, but they focus on U.S. current account and net financial flows, in contrast to our focus on gross financial flows. Both AG and AEK emphasize the importance of trend shocks in producing countercyclical trade balance and current account.

We study each shock separately and also study both shocks simultaneously, while varying the persistence of the transitory shock. Our paper's main contribution is to demonstrate that transitory shocks alone cannot produce results that are in line with the empirical evidence. Business cycle moments that are close to the data are only produced when trend shocks are present, regardless of the level of persistence of the transitory shock. A very persistent transitory shock alone also does not yield the rich cyclical dynamics we observe in the data. This demonstrates that our main finding does not depend on the persistence of transitory shocks but rather the separation of the transitory and trend shocks.

In our two-country setup with two financial assets, whose returns are contingent on the realizations of endowment, financial flows are generated by adjustments to portfolio holdings. The varying responses of consumption and national saving paths to both the level and trend shocks cause changes in the portfolio holdings of both domestic and foreign consumers. While a positive level shock causes an increase in both gross holdings of foreign assets and liabilities, a positive trend shock causes a decline in gross foreign assets and an increase in liabilities. With the positive trend shock, productivity increase that lasts many periods triggers an increase in demand for domestic asset, both by home and foreign consumers. Consequently, we observe a decline in home purchases of foreign asset. In response to a transitory shock, however, home agents increase their demand for 
both home and foreign assets as they seek a diversified strategy to invest the windfall.

This asymmetric response to trend and transitory shocks in portfolio holdings is the main mechanism that produces the disparate cyclical patterns of gross flows. Our results show that, while trend shocks yield weakly countercyclical gross outflows and weakly procyclical gross inflows, transitory shocks result in strongly procyclical flows. This main finding is independent of the assumptions about cross-country output correlations. Contessi et al. (2013) report that over 1992-2005 time period, the average output correlations for advanced economies' total inflows and outflows were estimated as 0.08 , and -0.02 respectively. Employing those correlations does not affect the cyclical properties of the flows.

It is important to understand gross flows and their cyclical properties for three main reasons. First, investigating the second-moment and cyclical properties of capital flows may help explain the heterogeneity observed in risk sharing achieved through international lending and borrowing. Second, treating international capital flows as adjustments to country portfolios in response to exogenous shocks can guide the calibration of models incorporating country portfolios. Through estimation of foreign and domestic productivity processes simultaneously, one could observe the different portfolio choices made by domestic and foreign investors, which result in the aforementioned portfolio reallocations and adjustments. Depending on the portfolio composition of the countries and on the dominant shock driving the output fluctuations, the cyclical properties of capital flows will change dramatically. And thus, as a third reason, understanding the relationship between growth and dynamics of international capital flows could be valuable for answering questions related to capital controls and monetary policy.

The rest of the paper proceeds as follows. Section 2 describes the model. Section 3 documents the baseline calibration and develops intuition with impulse response functions. Section 4 presents our quantitative results and compares theoretical correlation coefficients with the data. Section 5 concludes.

\section{Model}

The model is a two-country, two-good DSGE model with trend and transitory productivity shocks, where countries trade goods and financial assets. Country-specific variables are indexed with the superscript $i \in\{H$, $F$, where $H$ is the home country and $F$ is foreign. Countries are completely symmetric.

\subsection{Stochastic Endowment}

Each country receives a stochastic endowment of the country-specific good. The endowment of country $i, y_{t}^{i}$, is determined by the below stochastic process,

$$
y_{t}^{i}=e^{z_{t}^{i}}\left(\Gamma_{t}^{i}\right)
$$

where $z_{t}^{i}$ is the "transitory" and $\Gamma_{t}^{i}$ is the "permanent" component of the endowment. $z_{t}^{i}$ follows an AR(1) process:

$$
z_{t}^{i}=\rho_{z}^{i} z_{t-1}^{i}+\epsilon_{t}^{z, i}
$$

while $\Gamma_{t}^{i}$ has a stochastic growth rate and evolves according to:

$$
\begin{aligned}
\Gamma_{t}^{H} & =\Gamma_{t-1}^{H} e^{g_{t}^{H}} \pi_{t}^{\lambda} \\
\Gamma_{t}^{F} & =\Gamma_{t-1}^{F} e^{g_{t}^{F}} \pi_{t}^{-\lambda}
\end{aligned}
$$

$\pi_{t}$ is a convergence process, as in Nguyen (2011):

$$
\pi_{t} \equiv \frac{\Gamma_{t-1}^{F}}{\Gamma_{t-1}^{H}}=e^{g_{t-1}^{F}-g_{t-1}^{H}} \pi_{t-1}^{1-2 \lambda}
$$

The purpose of the convergence process is to keep the detrended model strictly stationary, so that local solution methods can be applied. In other words, even though the country productivities diverge for some time, $\pi_{t}$ guarantees that the overall process is consistent with absolute long run convergence. (Note 1) $g_{t}^{i}$ evolves as follows:

$$
g_{t}^{i}=\left(1-\rho_{g}^{i}\right) \bar{g}+\rho_{g}^{i} g_{t-1}^{i}+\epsilon_{t}^{g, i}
$$

where $\bar{g}$ is the long-run growth rate of productivity. Both countries have the same long- run growth rate. $\epsilon_{t}$, defined below, is a vector of normal, independently and identically distributed, mean-zero shocks with variance-covariance matrix $\Sigma$ : 


$$
\epsilon_{t} \equiv\left(\epsilon_{t}^{g, H}, \epsilon_{t}^{Z, H}, \epsilon_{t}^{g, F}, \epsilon_{t}^{z, F}\right)^{\prime}
$$

$\epsilon_{t}^{g, i}$ is referred to as "trend" shock, and $\epsilon_{t}^{z, i}$ is as "transitory" shock. In the model, households can perfectly identify trend from transitory shocks. Trend and transitory shocks are uncorrelated within each country; however, they may be correlated across countries. Let $\rho_{g}^{H, F}$ denote the cross-country correlation between trend shocks, and let $\rho_{z}^{H, F}$ denote the cross-country correlation between transitory shocks. Then we have:

$$
\begin{aligned}
& \mathrm{E}\left[\epsilon_{t}^{g, H}, \epsilon_{t}^{g, F}\right]=\rho_{g}^{H, F} \sigma_{g}^{H} \sigma_{g}^{F} \\
& \mathrm{E}\left[\epsilon_{t}^{z, H}, \epsilon_{t}^{z, F}\right]=\rho_{z}^{H, F} \sigma_{z}^{H} \sigma_{z}^{F}
\end{aligned}
$$

where $\sigma_{j}^{i}$ denotes the standard deviation of shock type $j \in\{g, z\}$ in country $i$.

\subsection{Households}

There is a unit mass of households in each country. Households within a country are identical, but preferences may vary across the countries. A representative household in country $i$ likes to consume baskets of home and foreign goods:

$$
c_{t}^{i}=\left[\omega^{\frac{1}{\phi}}\left(c_{t}^{i, i}\right)^{\frac{\phi-1}{\phi}}+(1-\omega)^{\frac{1}{\phi}}\left(c_{t}^{i,-i}\right)^{\frac{\phi-1}{\phi}}\right]^{\frac{\phi}{\phi-1}}
$$

$c_{t}^{i, i}$ is consumption of the domestically produced good, and $c_{t}^{i,-i}$ is consumption of the other country's good. $\phi$ is the elasticity of substitution between goods, and $\omega \in(0,1)$ is the weight of the domestic good in the basket. In the calibration, the standard assumption of consumption home bias is imposed by setting $\omega>1 / 2$.

Households can internationally trade a home and a foreign asset. These asset holdings make up the portfolio of each household and they earn financial income from their portfolio. At the start of period t, households observe the endowment and their financial income and they then decide how much of each good to consume, and how much of each asset to hold next period to maximize their expected present discounted utility:

$$
\begin{gathered}
\max \mathrm{E}\left[\sum_{j=0}^{\infty} \psi_{j}^{i} \frac{\left(c_{t+j}^{i}\right)^{1-\sigma}}{1-\sigma}\right] \\
\text { s.t. } r_{t}^{i} A_{t-1}^{i, i}+r_{t}^{-i} A_{t-1}^{i,-i}=A_{t}^{i, i}+A_{t}^{i,-i}+p_{t}^{i, c} c_{t}^{i}
\end{gathered}
$$

$\sigma>0$ is the coefficient of relative risk aversion. $\psi_{j}^{i}$ is an endogenous discount factor:

$$
\psi_{t+1}^{i}=(\beta)^{t} \prod_{k=0}^{t}\left(c_{k}^{i, a}\right)^{-\eta}
$$

$\beta \in(0,1)$ is the subjective discount factor, and $\left(c^{i, a}\right)$ is the country $i$ 's aggregate consumption. The use of the uninternalized endogenous discount factor is to ensure stationarity. As in Schmitt-Grohé and Uribe (2003), this is a simple technical device to induce uniqueness of the deterministic steady state and stationary responses to temporary shocks. Specifically, the endogenous discount factor decreases with aggregate consumption, which the representative household takes as given (Note 2).

$A^{i, j}$ denotes country $i$ 's holdings of country $j$ asset. The home (foreign) asset promises a share of the home (foreign) endowment. Let $q_{t}^{i}$ be the price of the asset associated with country $i$ 's endowment. Therefore, one can define the return on the asset $i$ as:

$$
r_{t}^{i}=\frac{\left(q_{t}^{i}+p_{t}^{i} y_{t}^{i}\right)}{q_{t-1}^{i}}
$$

$p_{t}^{i}$ is the price of the good produced in country $i . p_{t}^{i, c}$ is the consumer price index in country $i$, defined as follows:

$$
p_{t}^{i, c}=\left[\omega\left(p_{t}^{i}\right)^{1-\phi}+(1-\omega)\left(p_{t}^{-i}\right)^{1-\phi}\right]^{\frac{1}{1-\phi}}
$$

The numeraire is an equally weighted geometric average of the home and foreign consumer price indices:

$$
\left(p_{t}^{H, c}\right)^{\frac{1}{2}}\left(p_{t}^{F, c}\right)^{\frac{1}{2}}=1
$$

\subsection{Market Clearing}

The market-clearing conditions for the two goods are: 


$$
\begin{gathered}
y_{t}^{H}=c_{t}^{H, H}+c_{t}^{F, H} \\
y_{t}^{F}=c_{t}^{F, F}+c_{t}^{H, F}
\end{gathered}
$$

Similarly, the market clearing conditions for the asset holdings are:

$$
\begin{gathered}
q_{t}^{H}=A_{t}^{H, H}+A_{t}^{F, H} \\
q_{t}^{F}=A_{t}^{F, F}+A_{t}^{H, F}
\end{gathered}
$$

\subsection{Equilibrium Conditions}

Households maximize (5) with respect to (6) and (4). The first-order conditions for the home household can be written as follows:

$$
\begin{array}{ll}
c_{t}^{H, H}: & c_{t}^{H, H}=\omega\left(\frac{p_{t}^{H}}{p_{t}^{H, c}}\right)^{-\phi} c_{t}^{H} \\
c_{t}^{H, F}: & c_{t}^{H, F}=(1-\omega)\left(\frac{p_{t}^{F}}{p_{t}^{H, c}}\right)^{-\phi} c_{t}^{H} \\
A_{t}^{H, F}: & E_{t}\left[m_{t+1, t}^{H} r_{t+1}^{F}\right]=1 \\
A_{t}^{H, H}: & E_{t}\left[m_{t+1, t}^{H} r_{t+1}^{H}\right]=1
\end{array}
$$

$m_{t+j, t}^{i}$ is the stochastic discount factor for the consumer and it is as follows:

$$
m_{t+j, t}^{i}=\psi_{t+1}^{i}\left[\frac{c_{t+j}^{i}}{c_{t}^{i}}\right]^{-\sigma}\left(\frac{p_{t}^{i, c}}{p_{t+j}^{i, c}}\right)
$$

The first-order conditions for the foreign household are similar:

$$
\begin{array}{ll}
c_{t}^{F, F}: & c_{t}^{F, F}=\omega\left(\frac{p_{t}^{F}}{p_{t}^{F, c}}\right)^{-\phi} c_{t}^{F} \\
c_{t}^{F, H}: & c_{t}^{F, H}=(1-\omega)\left(\frac{p_{t}^{H}}{p_{t}^{H, c}}\right)^{-\phi} c_{t}^{F} \\
A_{t}^{F, F}: & E_{t}\left[m_{t+1, t}^{F} r_{t+1}^{F}\right]=1 \\
A_{t}^{F, H}: & E_{t}\left[m_{t+1, t}^{F} r_{t+1}^{H}\right]=1
\end{array}
$$

\section{Parameterization and Impulse Responses}

In this section, we document the baseline parameterization and develop intuition for the model dynamics with impulse response functions.

\subsection{Solution Method}

The model is solved using the methodology described by Devereux and Sutherland $(2010,2011)$. The standard log-linear approximation procedures cannot be applied to DSGE models with portfolio choice problems due to the indeterminacy of the equilibrium portfolio holdings. This solution method involves approximation of the non-portfolio and portfolio equations of the model to different degrees of accuracy in order to uniquely determine the near non-stochastic steady state (zero-order) and time varying portfolio holdings (first-order) in a DSGE model. That is, to solve for the $n$ th-order accurate portfolio holdings, portfolio optimality conditions need to be approximated to the order $n+2$.

Following Devereux and Sutherland (2010), we define country $i$ 's financial wealth as

$$
w_{t}^{i}=A_{t}^{i, i}+A_{t}^{i,-i}
$$

and rewrite country $i$ 's budget constraint as:

$$
w_{t}^{i}=w_{t-1}^{i} r_{t}^{F}+A_{t-1}^{i, H}\left(r_{t}^{H}-r_{t}^{F}\right)-p_{t}^{i, c} c_{t}^{i}
$$

The first-order condition for the choice of $A_{t}^{i, H}$ can be written in the following form: 


$$
E\left[\left(c_{t+1}^{i}\right)^{-\sigma}\left(p_{t+1}^{i, c}\right)^{-1} r_{t+1}^{H}\right]=E\left[\left(c_{t+1}^{i}\right)^{-\sigma}\left(p_{t+1}^{i, c}\right)^{-1} r_{t+1}^{F}\right]
$$

Taking a second-order log-approximation of this portfolio first-order condition (24) for both the home and the foreign households and subtracting, we derive the portfolio optimality condition:

$$
E\left[\left(\sigma\left(\hat{c}_{t+1}^{H}-\hat{c}_{t+1}^{F}\right)+\left(\hat{p}_{t+1}^{i, H}-\hat{p}_{t+1}^{i, F}\right)\right)\left(\hat{r}_{t+1}^{H}-\hat{r}_{t+1}^{F}\right)\right]=0
$$

Variables with hat " $\hat{x}$ " are log deviations from their steady state values. Devereux and Sutherland (2011) show that the steady state portfolio is the one that satisfies (25). To solve for the time-varying equilibrium portfolio holdings, equation (24) is approximated to a third-order accuracy and third-order equivalent of (25) is derived. See Devereux and Sutherland (2011) for further details on the solution method.

Table 1. Baseline parameterization

\begin{tabular}{ccl}
\hline Parameter & Value & \multicolumn{1}{c}{ Description } \\
\hline$\sigma$ & 2 & Coefficient of relative risk aversion \\
$\beta$ & 0.98 & Discount factor \\
$\eta$ & 0.001 & Endogenous discount factor \\
$\omega$ & 0.85 & Weight of domestic good in consumption \\
$\phi$ & 5 & Elasticity of substitution between goods \\
$\bar{g}$ & 0.01 & Long-run growth rate \\
$\lambda$ & 0.001 & Convergence parameter for growth processes \\
$\rho_{g}^{i}$ & 0.55 & Persistence of trend productivity process \\
$\rho_{z}^{i}$ & 0.7 & Persistence of transitory productivity process \\
\hline
\end{tabular}

\subsection{Parameterization}

The focus of this analysis is the financial flows between two symmetric advanced economies. The pair of U.S. and G6, that is, the G7 countries minus the U.S., is considered as the benchmark case. Time frequency is quarterly. Table 1 presents the baseline parameter values used. The parameters $\sigma$ (coefficient of relative risk aversion), and $\beta$ (discount factor) are the same as in AEK and are standard in the literature. Due to the two-good model setup, there are two parameters governing households' preferences over home and foreign goods. Following Coeurdacier et al. (2010), $\omega$ (the weight on domestic goods in the consumption basket) is set to 0.85 , corresponding to a steady state import share of $15 \% . \phi$ is set to 5, as in Coeurdacier (2009). (Note 3) Steady state growth rate is set to 0.01 , which is approximately the average quarterly growth rate of U.S. real GDP over 1960-2009. The convergence parameters $\lambda$ and $\eta$ are set to 0.001 , which are standard in the literature (see, e.g., Nguyen, 2011; Guerrieri, Henderson, \& Kim, 2005). $\rho_{g}^{i}$ and $\rho_{z}^{i}$ are set to 0.55 and 0.7 for both the U.S. and the G6, respectively. These estimates are from Nguyen (2011), based on the data from 1960-2000.

\subsection{Impulse Responses}

We consider positive, one-standard deviation shocks to the trend and transitory productivity in the home country. This amounts to a $0.1 \%$ trend home shock and a $1 \%$ transitory home shock. Figure 1 shows the impulse responses for several of the key endogenous variables. Figure 2 shows the changes in home wealth and the home household portfolio holdings in response to the positive transitory and trend shocks. Wealth is defined as in equation (22), while net foreign asset (NFA) is defined as the difference between foreign asset holdings and foreign liabilities:

$$
n f a_{t}^{i}=A_{t}^{i,-i}-A_{t}^{-i, i}
$$

In response to a positive transitory shock, the home country consumption-output ratio falls. Domestic agents understand that the shock is temporary; although they enjoy unexpectedly high productivity and income today. 

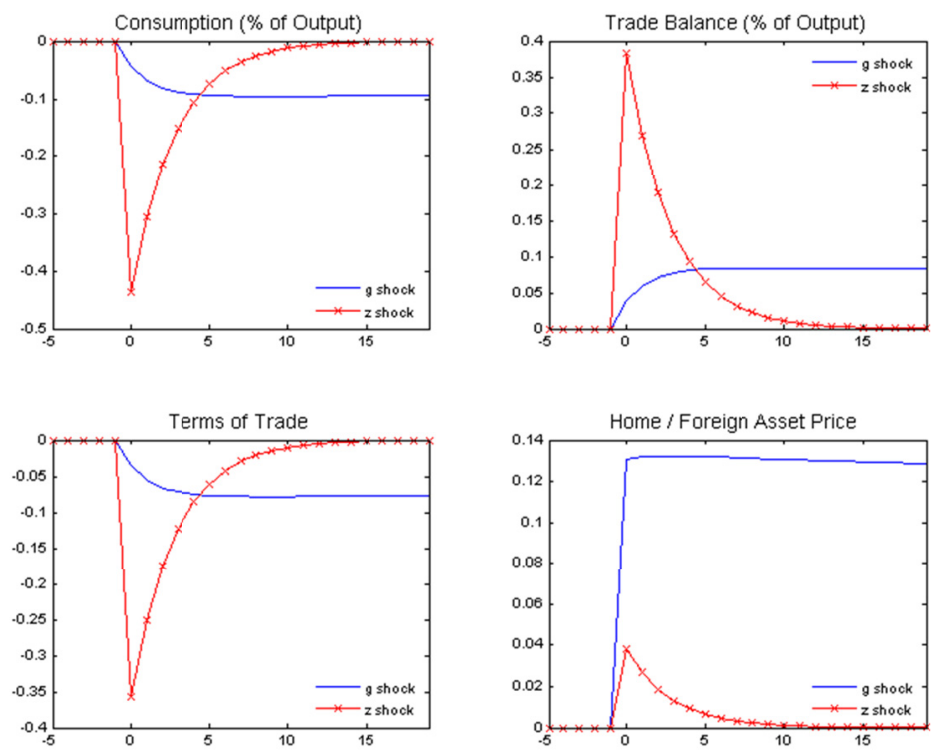

Figure 1. The impulse responses for several of the key endogenous variables

Note. Impulse responses to a $1 \%$ transitory $(z)$ shock and a $0.1 \%$ trend $(g)$ shock. All responses are percent deviations from steady state values.
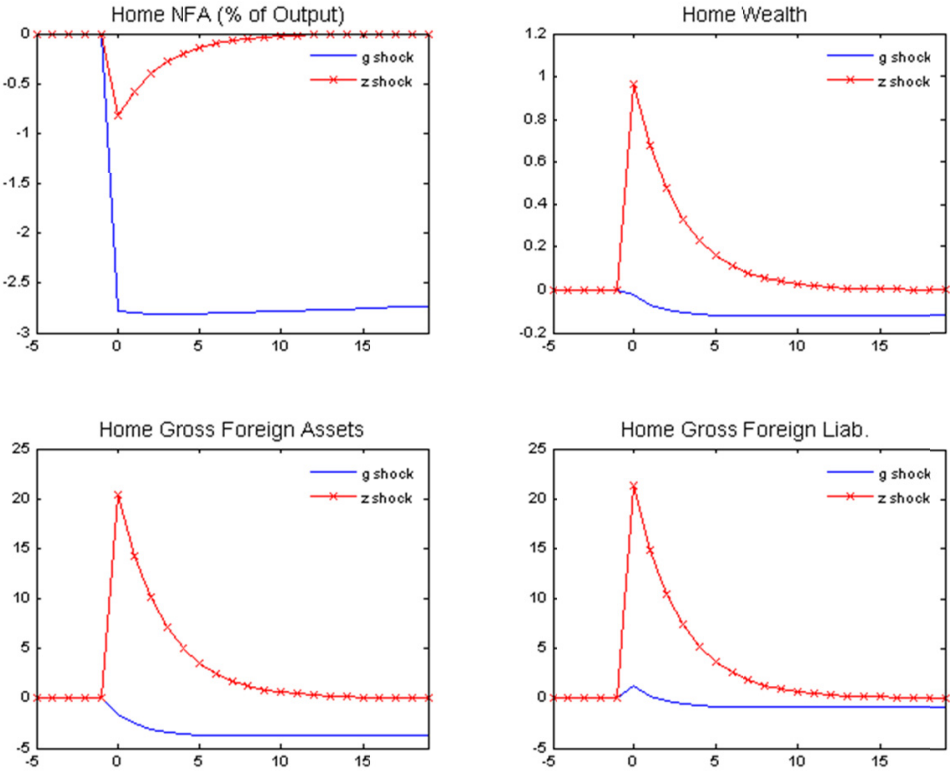

Figure 2. The changes in home wealth and the home household portfolio holdings

Note. Impulse responses to a $1 \%$ transitory $(z)$ shock and a $0.1 \%$ trend $(g)$ shock. All responses are percent deviations from steady state values.

They expect productivity to start falling tomorrow. In response, domestic households save a larger share of their income in order to smooth consumption over time. The increase in national saving pushes the share of trade balance towards surplus. Following a positive trend shock, the consumption-output ratio falls. The increase in endowment decreases the price of the home good, which causes the deterioration of the terms-of-trade of the home country. This increase in relative price of the foreign good makes foreign consumption more expensive for the home household. The drop in terms-of-trade is immediate and short-lived following a transitory shock, but gradual and long-lived following a trend shock. The increase in the rate of return for the home asset due to the increase in home endowment causes the price of the home asset to rise relative to the price of the foreign asset. 
This increase is smaller and short-lived following a transitory shock compared to the impact of a trend shock.

The main contribution of our analysis lies in exploring the different impact of the two productivity shocks studied on the household's wealth and portfolio allocations. In response to a positive transitory shock, home household's wealth rises. The bottom row of Figure 2 illustrates that this increase is due to the home country consumer increasing her holdings of both home and foreign assets. On net, as a result of the surge in demand for the home asset due to its higher rate of return, the increase in foreign liabilities dominates. Therefore, net foreign asset position of the country becomes negative. After a positive trend shock, home household experiences an immediate drop in her wealth. This drop gets larger until the peak productivity is reached, and then reverts slowly back. Portfolio models with highly persistent shocks exhibit large wealth effects and uninsurable consumption risk. This model shares these features. The deterioration of the terms of trade following an endowment rise increases the relative price of foreign good consumption. Subsequent to a positive trend shock, this effect is longer lasting. Home households find foreign goods more expensive, and foreign households find home goods more affordable. The result is a negative wealth effect for home households and a drop in their consumption path.

Another notable difference between the responses to the transitory and trend shocks is the change in gross asset holdings. The home agent experiences an increase in both gross foreign assets and liabilities after a transitory shock. Following a trend shock, gross foreign asset holdings decline, while gross foreign liabilities increase. Overall, the home country experiences a bigger drop in its net foreign assets following the trend shock. Due to the prolonged increase in home productivity and the return on home asset, home agents choose to hold a short position in foreign asset and a long position in domestic asset. This is an important result for the literature investigating the factors that determine the direction of capital flows and establish the cyclical patterns they possess. This result suggests that, in an episode of bigger shocks to the trend component of the output of a country, one could expect to observe countercyclical gross outflows. This is in clear contrast with the procyclical gross outflows that would be observed, if the shock were to hit the transitory component of the output.

\section{Quantitative Results}

We estimate the model using several different specifications of the productivity processes. This exercise allows us to identify and quantify the distinct implications of the trend and transitory shocks on the cyclicality of capital flows.

Table 2. Parameter specifications

\begin{tabular}{ccccccccc}
\hline \multicolumn{2}{l}{ Parameter Specifications } & \multicolumn{1}{l}{} \\
\hline \multicolumn{2}{c}{$\rho_{g}^{H}$} & $\rho_{g}^{F}$ & $\rho_{z}^{H}$ & $\rho_{z}^{F}$ & $\sigma_{g}^{H}$ & $\sigma_{g}^{F}$ & $\sigma_{z}^{H}$ & $\sigma_{z}^{F}$ \\
\hline 1 & & & 0.99 & 0.99 & & & 0.10 & 0.10 \\
2 & 0.55 & 0.55 & & & 0.10 & 0.10 & & \\
3 & 0.55 & 0.55 & 0.70 & 0.70 & 0.10 & 0.10 & 0.10 & 0.10 \\
4 & 0.55 & 0.55 & 0.95 & 0.95 & 0.10 & 0.10 & 0.10 & 0.10 \\
\hline
\end{tabular}

Table 2 explains the set of parameter specifications used for the productivity processes analyzed. $\rho_{\mathrm{j}}^{\mathrm{i}}$ denotes the persistence of the shock $j, j \in\{g, z\}$, of the country $i, i \in\{H, F\}$, while $\sigma_{j}^{i}$ denotes the standard deviation of each shock. In the first specification, the only shock is a very persistent transitory shock, which is symmetric across the two countries. Therefore specification 1 sets standard deviations of the trend shocks to zero; i.e. $\sigma_{g}^{H}=\sigma_{g}^{F}=0$. Specification 2 is the opposite scenario, where we only have trend shocks and hence $\sigma_{z}^{H}=\sigma_{z}^{F}=$ 0 . Specifications 3 and 4 include both shocks. The difference between them is the higher persistence of the transitory shock under specification 4 . Specification 4 highlights the role of trend shocks, when the country also receives very persistent transitory shocks.

Table 3 displays predictions of the model for correlations of gross and net financial flows with the endowment under each of the parameter specifications. We assume productivity processes are not correlated across the two countries. The first two columns of Table 3 represent empirical values for the predicted correlation coefficients. These empirical values for the U.S. and the G7 are from Contessi et al. (2013). They report the output correlation coefficients for the U.S. total inflows and outflows as 0.11 and -0.01 , respectively, over 1975-2005. Net U.S. total outflows over the same time period has a correlation coefficient of -0.20 . Their net outflow measure matches with our measure of net foreign assets. Over the same time period, the G7 average for total inflows and outflows were 0.10 and 0.04 , respectively, with the correlation for net outflows at -0.13 . Over 1992-2005 time 
period, the average output correlations for advanced economies' total inflows and outflows were estimated as 0.08 , and -0.02 , respectively (Note 4 ).

Table 3. Correlations with endowment

\begin{tabular}{lrlcccc}
\hline & \multicolumn{3}{c}{ Data } & \multicolumn{4}{c}{ Model predictions } \\
\cline { 2 - 7 } & U.S. & G7 & 1 & 2 & 3 & 4 \\
\hline Gross foreign assets & -0.01 & 0.04 & 0.42 & -0.01 & 0.02 & 0.05 \\
Gross foreign liabilities & 0.11 & 0.10 & 0.91 & 0.08 & 0.15 & 0.29 \\
Net foreign assets & -0.20 & -0.13 & -0.71 & -0.04 & -0.03 & -0.04 \\
\hline
\end{tabular}

Under the first specification, where there is only a very persistent transitory shock to the endowment, both gross inflows and outflows display a strong positive correlation with the endowment. By contrast, following specification 2, when there is only a trend shock, comovements with the endowment are substantially weaker and these lower coefficients are more aligned with the data. Another striking difference between the first two specification results is the asymmetric cyclical behavior of the gross outflows. Gross foreign assets display countercyclical behavior with only trend shock. As also was the case in the impulse responses, gross foreign assets are negatively correlated with the trend shock while they are positively correlated with the transitory shock. Net foreign assets display countercyclical behavior under both cases, but the correlation coefficient drops in magnitude under the second specification.

The last two columns present the results from a mix of trend and transitory shocks. When both shocks are analyzed simultaneously, the coefficients remain small. One notable difference from the second specification is that the gross foreign assets no longer display countercyclical behavior. Comparing specifications 3 and 4, as the persistency of the transitory shocks increases, the correlations between gross flows and endowments increase. Nevertheless, they remain considerably smaller compared to the first specification, where only persistent transitory shocks were employed.

Table 4. Non-zero cross-country correlations

\begin{tabular}{lrlcccc}
\hline & \multicolumn{3}{c}{ Data } & \multicolumn{4}{c}{ Model predictions } \\
\cline { 2 - 7 } & U.S. & G7 & 1 & 2 & 3 & 4 \\
\hline Gross foreign assets & -0.01 & 0.04 & 0.85 & -0.01 & 0.05 & 0.13 \\
Gross foreign liabilities & 0.11 & 0.10 & 0.97 & 0.05 & 0.25 & 0.49 \\
Net foreign assets & -0.20 & -0.13 & -0.39 & -0.03 & -0.02 & -0.02 \\
\hline
\end{tabular}

Note. The results are under non-zero cross-country correlation assumption. Specifically, the cross-country transitory shock correlation is set at 0.7 , while the cross-country trend shock correlation is set at 0.4 . These values are taken from the estimates of AEK for the U.S. and G6.

Table 4 presents the results from the specifications explained in Table 2, this time assuming that the cross-country productivity correlations are non-zero. With the introduction of the cross-country correlations, we observe an overall increase in the magnitudes of the correlation coefficients. This result is due to the less severe negative wealth effect through the deteriorating terms of trade. Following a positive shock the home country endowment, the foreign output increases along with the home output. The spillover effect causes the price of the foreign good to also experience a decline, which makes foreign good consumption less expensive for the home country agents, dampening the negative wealth effect. The cyclical behavior of the gross flows remains otherwise similar to those from the zero cross-correlation case.

While any country specific predictions are beyond the scope of this paper, the closeness of the predictions of our model to the empirical values from the literature is of interest. The heterogeneous results observed in the data can be achieved through the joint estimation of the trend and transitory shocks for country groups. This is not likely in the presence of transitory shocks only. Appendix A summarizes the results from an exercise, in which we use estimated standard deviations for the shocks to the U.S. and G6 countries. Table A1 explains the specifications, which are taken from AEK's estimation results. The weakly countercyclical nature of the outflows and relatively stronger procyclical nature of the inflows provide evidence in support of the main finding of our paper.

Our theoretical predictions demonstrate that trend shocks yield weakly countercyclical gross outflows and 
weakly procyclical gross inflows, while transitory shocks result in strongly procyclical gross flows. This is a significant finding; one that reveals the different implications of the trend and transitory shocks to the output as drivers of financial flows and demonstrates that the separate modeling of fluctuations in transitory and trend components of output yields results superior to the standard setup of the open economy models with transitory productivity shocks only.

\section{Conclusion}

This paper analyzes the behavior of international gross capital flows over the business cycle in a two-country DSGE portfolio choice model with shocks to both the transitory and trend components of the endowment. Despite the simplicity of the model, the results manifest that trend shocks have an entirely different impact on the composition of the portfolio holdings of a country compared to a model of the economy with transitory shocks solely, even if they are very persistent.

Especially gross foreign asset holdings respond significantly differently to the nature of the productivity shock. While a transitory increase in the endowment is invested in both foreign and domestic assets, following a positive trend shock, the home agent reduces its holdings of the foreign asset. This adjustment in portfolio stems from the prolonged increase in home productivity, which prompts the home country agent to switch a portion of her wealth out of the foreign assets and to the home assets. The countercyclical behavior of the net foreign assets is prevalent across all the productivity specifications; however the magnitude of the coefficients is closer to the data only in the presence of trend shocks.

A comparison of the data and the theoretical predictions of our model illustrates that the transitory shocks alone cannot yield the variety of the observed cyclical dynamics of the gross international financial flows. As future research, we intend to evaluate the robustness of these results under a more general setup of the economy with investment, as investment is a significant driving force for the international borrowing and lending of economies, but economic intuition tells that inclusion of investment dynamics would only reinforce the above presented results.

\section{Acknowledgements}

The author gratefully acknowledges feedback from Yamin Ahmad, and all research funding from University of Wisconsin - Whitewater. All errors are my own.

\section{References}

Aguiar, M., \& Gopinath, G. (2007). The emerging market business cycles: The cycle is the trend. Journal of Political Economy, 115(1), 69-102. http://dx.doi.org/10.1086/511283

Amdur, D., \& Ersal-Kiziler. (2014). Trend shocks and the countercyclical U.S. current account. Canadian Journal of Economics, 47(2), 495-516. http://dx.doi.org/10.1111/caje.12087

Baxter, M., \& Crucini, M. (1995). Business cycles and the asset structure of foreign trade. International Economic Review, 36(4), 821-854. http://dx.doi.org/10.2307/2527261

Blonigen, B. A., Piger, J., \& Sly, N. (2014). Comovement in GDP trends and cycles among trading partners. Journal of International Economics, 94(2), 239-247. http://dx.doi.org/10.1016/j.jinteco.2014.06.008

Broner, F., \& Rigobon, R. (2006). Why are capital flows so much more volatile in emerging than in developed countries? In R. Caballero, C. Calderón, L. F. Céspedes, N. Loayza, \& K. Schmidt-Hebbel (Eds.), Central banking, analysis, and economic policies book series (Vol. 3, pp. 15-40). Chile: Central Bank of Chile.

Broner, F., Didier, T., Erce, A., \& Schmukler, S. L. (2013). Gross capital flows: Dynamics and crises. Journal of Monetary Economics, 60(1), 113-133. http://dx.doi.org/10.1016/j.jmoneco.2012.12.004

Chen, K., \& Crucini, M. (2014). Trends and cycles in small open economies: Making the case for a general equilibrium approach. Federal Bank of Dallas Globalization and Monetary Policy Institute Working Paper 217. Dallas, TX: U.S. Federal Bank of Dallas. Retrieved February 19, 2015, from http://www.dallasfed.org/assets/documents/institute/wpapers/2014/0217.pdf

Coeurdacier, N. (2009). Do trade costs in goods markets lead to home bias in equities? Journal of International Economics, 77, 86-100. http://dx.doi.org/10.1016/j.jinteco.2008.10.005

Coeurdacier, N., Kollman, R., \& Martin, P. (2010). International portfolios, capital accumulation and foreign asset dynamics. Journal of International Economics, $80,100-112$. http://dx.doi.org/10.1016/j.jinteco.2009.05.006

Contessi, S., De Pace, P., \& Francis, J. L. (2013). The cyclical properties of disaggregated capital flows. Journal 
of International Money and Finance, 32, 528-555. http://dx.doi.org/10.1016/j.jimonfin.2012.05.023

Corsetti, G., Dedola, L., \& Leduc, S. (2008). International risk sharing and the transmission of productivity shocks. Review of Economic Studies, 75. http://dx.doi.org/10.1111/j.1467-937X.2008.00475.x

Crucini, M., Kose, A., \& Otrok, C. (2011). What are the driving forces of international business cycles? Review of Economic Dynamics, 14(1), 156-175. http://dx.doi.org/10.1016/j.red.2010.09.001

Devereux, M. B., \& Sutherland, A. (2010). Country portfolio dynamics. Journal of Economic Dynamics and Control, 34, 1325-1342. http://dx.doi.org/10.1016/j.jedc.2010.03.008

Devereux, M. B., \& Sutherland, A. (2011). Country portfolios in open economy macro-models. Journal of the European Economic Association, 9(2), 337-369. http://dx.doi.org/10.1111/j.1542-4774.2010.01010.x

Evans, M. D. D., \& Hnatkovska, V. (2012). A method for solving general equilibrium models with incomplete markets and many financial assets. Journal of Economic Dynamics and Control, 36(12), 1909-1930. http://dx.doi.org/10.1016/j.jedc.2012.05.010

Forbes, K., \& Warnock, F. (2012). Capital flow waves: Surges, stops, flight, retrenchment. Journal of International Economics, 88(2), 235-251. http://dx.doi.org/10.1016/j.jinteco.2012.03.006

Garcia-Cicco, J., Pancrazi, R., \& Uribe, M. (2010). Real business cycles in emerging economies. American Economic Review, 100(5), 2510-2531. http://dx.doi.org/10.1257/aer.100.5.2510

Guerrieri, L., Henderson, D., \& Kim, J. (2005). Investment-specific and multifactor productivity in multi-sector open economies: Data and analysis. International Finance Discussion Paper 828. Washington, D.C.: U.S. Board of Governors of the Federal Reserve System. http://dx.doi.org/10.2139/ssrn.681410

Kaminsky, G. L., Reinhart, C. M., \& Végh, C. A. (2005). When it rains, it pours: Procyclical capital flows and macroeconomic policies. In M. Gertler, \& K. Rogoff (Eds.), NBER Macroeconomics Annual 2004 (Vol. 19, pp. 11-82). Cambridge, MA: MIT Press.

Levy-Yeyati, E., Panizza, U., \& Stein, E. E. (2007). The cyclical nature of north-south FDI flows. Journal of International Money and Finance, 26(1), 104-130. http://dx.doi.org/10.1016/j.jimonfin.2006.10.012

Nguyen, H. (2011). Valuation effects with transitory and trend productivity shocks. Journal of International Economics, 85(2), 245-255. http://dx.doi.org/10.1016/j.jinteco.2011.06.005

Rabanal, P., Rubio-Ramirez, J. F., \& Tuesta, V. (2011). Cointegrated TFP processes and international business cycles. Journal of Monetary Economics, 58(2), 156-171. http://dx.doi.org/10.1016/j.jmoneco.2011.03.005

Schmitt-Grohé, S., \& Uribe, M. (2003). Closing small open economy models. Journal of International Economics, 61, 163-185. http://dx.doi.org/10.1016/S0022-1996(02)00056-9

Tille, C., \& Van Wincoop, E. (2010). International capital flows. Journal of International Economics, 80(2), 157-175. http://dx.doi.org/10.1016/j.jinteco.2009.11.003

\section{Notes}

Note 1 . In the calibration, $\lambda$ is set a quite small number. The speed of convergence depends on the choice of parameter $\lambda$. When $\lambda>0$, the convergence process makes the productivity processes cointegrated across the countries. A small $\lambda$ means long convergence. See Rabanal, Rubio-Ramirez and Tuesta, 2009 for further information on cointegration of productivity processes in two-country models.

Note $2 . \eta$ will be assigned a very small value $(\eta=0.001)$, so that the impact of the endogenous discount factor on the model's dynamics is minimal.

Note 3. Following Coeurdacier (2009), we choose the lower bound of estimates from the trade literature. The results do not change much as long as $\phi$ is greater than about 1 . For very low values of $\phi$, a positive productivity shock at home reduces home's terms of trade dramatically, making home agents worse off. See Coeurdacier (2009) for details.

Note 4. Contessi et al. (2013) report that output correlations of total inflows and outflows for emerging markets are 0.10 and -0.08 , respectively. 


\section{Appendix A}

Quantitative Results with Estimated Trend and Transitory Shocks

Table A1.

\begin{tabular}{|c|c|c|c|c|c|c|c|c|}
\hline \multicolumn{9}{|c|}{ Parameter Specifications } \\
\hline & $\rho_{g}^{H}$ & $\overline{\rho_{g}^{F}}$ & $\rho_{z}^{H}$ & $\rho_{z}^{F}$ & $\sigma_{g}^{H}$ & $\overline{\sigma_{g}^{F}}$ & $\sigma_{z}^{H}$ & $\sigma_{z}^{F}$ \\
\hline 5 & 0.55 & 0.55 & 0.70 & 0.70 & 0.76 & 0.44 & 0.54 & 0.52 \\
\hline 6 & 0.48 & 0.41 & 0.70 & 0.70 & 0.84 & 0.54 & 0.53 & 0.51 \\
\hline 7 & 0.64 & 0.56 & 0.95 & 0.93 & 0.57 & 0.40 & 0.54 & 0.36 \\
\hline 8 & & & 0.99 & 0.98 & & & 0.87 & 0.67 \\
\hline 9 & 0.54 & 0.46 & & & 0.74 & 0.58 & & \\
\hline
\end{tabular}

Note. Values in this table are parameter specifications from different estimates of trend and transitory productivity processes for U.S. and G6 using data from 1960.2-2009.4. Specification 8 sets standard deviations of the trend shocks to zero; i.e. $\boldsymbol{\sigma}_{\boldsymbol{g}}^{\boldsymbol{H}}=\boldsymbol{\sigma}_{\boldsymbol{g}}^{\boldsymbol{F}}=\mathbf{0}$. Specification 9 sets standard deviations of the transitory shocks to zero and hence $\boldsymbol{\sigma}_{z}^{\boldsymbol{H}}=\boldsymbol{\sigma}_{\mathbf{z}}^{\boldsymbol{F}}=\mathbf{0}$. Cross-country correlations are zero under all specifications.

Table A2.

\begin{tabular}{lccccccc}
\hline & \multicolumn{3}{c}{ Data } & \multicolumn{5}{c}{ Model predictions } \\
\hline & U.S. & G7 & 5 & 6 & 7 & 8 & 9 \\
\cline { 2 - 8 } Gross foreign assets & -0.01 & 0.04 & -0.00 & 0.00 & 0.03 & 0.67 & -0.02 \\
Gross foreign liabilities & 0.11 & 0.10 & 0.14 & 0.15 & 0.27 & 0.96 & 0.08 \\
Net foreign assets & -0.20 & -0.13 & -0.05 & -0.05 & -0.05 & -0.93 & -0.06 \\
\hline
\end{tabular}

Table A2 represents the results of the model using the parameter specifications from Table A1. Specification 8 stands out with strong positive coefficients, similar to the earlier results with the transitory shocks only. The rest of the specifications produce somewhat similar results, where gross foreign outflows are acyclical on average with very low and at times negative correlation coefficients. Gross inflows display relatively stronger and consistently positive correlation coefficients

\section{Copyrights}

Copyright for this article is retained by the author(s), with first publication rights granted to the journal.

This is an open-access article distributed under the terms and conditions of the Creative Commons Attribution license (http://creativecommons.org/licenses/by/3.0/). 